\title{
Az egészséges környezethez való jog elméleti megközelítésben
}

\begin{abstract}
egészséges környezethez való jog - környezetvédelem - emberi jogok védelme motivációelmélet
\end{abstract}

\begin{abstract}
A környezeti tárgyú nemzetközi jogi dokumentumok 1972 óta tartó ${ }^{1}$ gyarapodásával párhuzamosan lett vizsgálatok tárgya a környezetvédelem és az emberi jogok védelmének kapcsolata. Az emberi jogok védelme és a környezetvédelem közötti összefüggések felismerése, valamint e két védelmi rendszer összekapcsolása hívta fel a figyelmet egy meghatározott tulajdonsággal bíró - egészséges - környezethez való jog elismerésének az igényére. A környezet védelme az emberiség akut feladatai között szerepel. A környezetet minden lehetséges eszközzel védeni kell, egyrészt önvédelmi okokból, másrészt morális kötelességből. Egy potenciális eszköz lehet a környezet emberi jogi eszközökkel történő védelme, amely az egészséges környezethez való jog megfelelő szabályozásában ölthet testet. De vajon illeszkedik-e ez az elképzelés az emberi jogok rendszerébe? Választ keresvén e kérdésre, az alábbiakban elemzem a környezeti jogok és az emberi jogok kapcsolatrendszerét, továbbá az emberi jogi attribútumokat, annak érdekében, hogy bemutassam, általában milyen feltételek alapján illeszkedhet egy jog az emberi jogok kategóriájába. Ezek alapján válaszolom meg a kérdést, hogy elméletileg illeszkedhet-e egy meghatározott tulajdonságú környezethez való jog az emberi jogok halmazába.
\end{abstract}

\section{A környezet és az emberi jogok kapcsolata}

C. G. Weeramantry, a Nemzetközi Bíróság volt alelnöke, a Bös-Nagymaros ügyben ${ }^{2}$ hozott ítélethez füzött különvéleményében kifejti, hogy környezetünk védelme „alapvető része az emberi jogok jelenleg érvényes doktrínájának, hiszen az számos emberi jognak, mint például az egészséghez, illetve az élethez való jognak sine qua non eleme [...] a környezetet ért károk az Egyetemes Nyilatkozatban és egyéb

* Dr. Hermann Veronika PhD-hallgató, Pécsi Tudományegyetem Állam- és Jogtudományi Kar Európa Központ, Pécs, greksza.veronika@ajk.pte.hu.

1 1972-ben Stockholmban került megrendezésre a nemzetközi környezetjog kezdetét jelentő ENSZ Környezeti Világkonferencia, mely során elfogadták az ún. Stockholmi Nyilatkozatot.

2 A bős-nagymarosi vízlépcsörendszerrel kapcsolatos ügy; Case concerning Gabcíkovo-Nagymaros Project, 25 September 1997. Az ítéletet lásd: http://www.icj-cij.org/docket/files/92/7375.pdf (2016. 04. 20.). 
emberi jogi okmányokban emlitett összes emberi jogot csorbithatják, illetve alááshatják". ${ }^{3}$

Az emberi jogok, valamint a környezet minősége és védelme között egy komplex összefüggésrendszer található, amely a jogtudományban már széles körben bizonyított és elfogadott. ${ }^{4} \mathrm{Az}$ emberi jogok az emberi élet és méltóság feltétlen tiszteletén alapulnak, míg a környezetvédelem célja a környezet állapotának fenntartása és/ vagy javítása. ${ }^{5} \mathrm{Az}$ ember számára a környezetvédelem és az emberi jogok védelme is kívánatos, mivel azok jobb életfeltételeket és életkörülményeket biztosítanak. Az ember puszta létezése, valamint életének minősége az élhető bolygó fenntartásától is függ, így a környezetszennyezés veszélyeztethet, illetve csorbíthat bizonyos emberi jogokat. Az ember számára egészséges környezet léte számos emberi jog elöfeltétele is egyben, gondoljunk csak az élethez, az egészséghez, a magán- és családi élethez vagy a tulajdonhoz való emberi jogokra. A környezet és az ember, valamint ezzel párhuzamosan a környezeti jogok (környezethez való alanyi jog, környezeti kérdések esetében információhoz való jog, döntéshozatalban való részvétel joga, valamint az igazságszolgáltatáshoz való jog) és az emberi jogok kapcsolatát taglaló nézetek alapvetően két pólus körül és között helyezkednek el, amelyeket leegyszerűsítve antropocentrikus, valamint ökocentrikus megközelítésnek szokás nevezni.
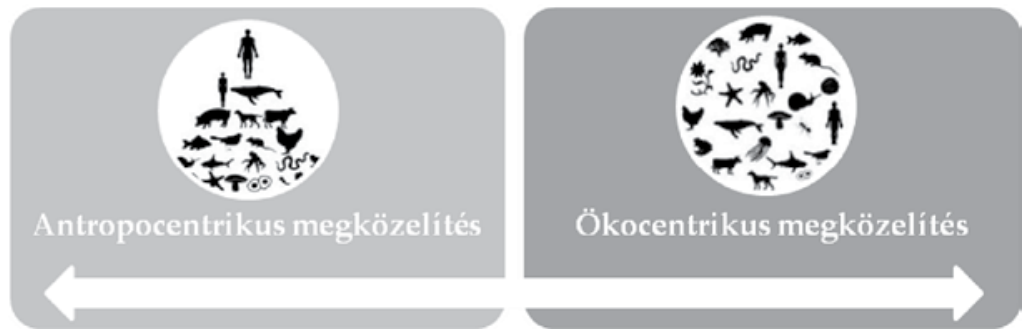

1. ábra. A környezet és az ember kapcsolatát vizsgáló nézetek két pólusa

3 Weeramantry bíró különvéleménye a Nemzetközi Bíróság elé terjesztett bős-nagymarosi vízlépcsőrendszerrel kapcsolatos ügyben. 91. b) pont. A különvéleményt lásd: http://www.icj-cij.org/docket/files/92/7383. pdf (2016. 01. 28.).

4 A környezet védelme és az emberi jogok közötti kapcsolatról bővebben lásd: BoYLE, Alan: Human Rights and the Environment: Where Next? In: Boer, Ben (ed.): Environmental Law Dimensions of Human Rights. Oxford University Press, Oxford, 2015; Birnie, Patricia-Boyle, Alan-Redgwell, Catherine (eds.): International Law and the Environment. Oxford University Press, New York, 2009; Boyle, Alan: Human Rights or Environmental Rights? A Reassessment. In: Shelton, Dinah (ed.): Human Rights and the Environment Volume. Edward Elgar Publishing, 2011; MushKat, Roda: Contextualizing Environmental Human Rights: A Relativist Perspective. In: Shelton, Dinah (ed.): Human Rights and the Environment Volume I. Edward Elgar Publishing; BÁNDı Gyula: Gondolatok a környezethez való jogról. In: Raisz Anikó (szerk.): A nemzetközi közjog aktuális kihívásai. Miskolci Egyetem, Miskolc, 2012; NickEL, James-Magraw, Daniel: Philosophical Issues in International Environmental Law. In: Besson, Samantha-Tasioulas, John (eds.): The Philosophy of International Law. Oxford University Press, Oxford, 2010; HISKES, Richard: The Rights to a Green Future: Human Rights, Environmentalism, and Intergenerational Justice. Human Rights Quarterly, 2005, 1346-1364; SHELTON (1991-1992) i. m., 103-130; Fitzmaurice, Malgosia: Environmental Degradation. In: Moeckli, Daniel-Shah, Sangeeta-Sivakumaran, Sandesh (eds.): International Human Rights Law. Oxford University Press, 2. kiadás, 2014.

5 BÁNDI Gyula: Környezetjog. Szent István Társulat, Budapest, 2011, 12. 


\subsection{Antropocentrikus megközelítés}

Az antropocentrikus megközelítés a polgári és politikai jogok „zöldebbé” tétele mellett érvel. E megközelítés szerint bizonyos, már elismert és védett, első generációs polgári és politikai jogokon keresztül védhetőek meghatározott környezeti jogok, mint például az információhoz való jog, a döntéshozatalban való részvétel, illetve a jogorvoshoz való jog (a környezethez való jog eljárási oldala). A környezethez való jog eljárási oldalának erősítése által az államok védelemben tudják részesíteni az egyén életét, magánéletét és tulajdonát, a környezeti károkozással szemben, külön környezethez való alanyi jog elismerése nélkül. Más szóval, a környezetvédelmi célok eléréséhez a releváns, már meglévő emberi jogokat (garanciákat és intézményeket) veszi igénybe a környezetvédelem általában (de nem minden esetben) akkor, amikor a környezeti kár bekövetkezik.

$A z$ antropocentrikus megközelítés az egyéneket ért károkra koncentrál, és a környezetet áruként (mere good) kezeli, amely az emberi jogok rendszerében az egyéni szükségletek kielégítését szolgálja. Értéktársítás tehát nem történik. Ez a nézet nem tekinti önálló emberi jognak az egészséges környezethez való jogot, így az alanyi jogként meg sem jelenhet, és a kollektív alanyi kör is kizárt. Ez az egészséges környezethez való jog klasszikus felfogása. E nézet képviselői általában nem is használják az egészséges környezethez való jog kifejezést, mivel azt nem ismerik el önálló jognak. E nézet alapján nem létezik önálló egészséges környezethez való jog, csupán a már el/felismert jogoknak van környezeti dimenziójuk. Az élethez való jog, a magán- és családi élethez való jog, valamint a tulajdonhoz való jog sérülhet környezeti károkozás által. E jogok környezeti károkozástól való védelme az információhoz való jogban, a döntéshozatalban való részvételben és az igazságszolgáltatáshoz való jogban csúcsosodik ki. Indokolt vajon a hatékonyság érdekében az ilyen szűk értelmezés? Valóban lefedi ez a megközelítés a lehetséges jogsérelmek körét?

\section{2. Ökocentrikus megközelítés}

Az ökocentrikus megközelítés, amely az antropocentrikus felfogás ellenpólusa, az egészséges környezethez való jogot már szolidaritási jogként képzeli el. E felfogás kiindulópontja a környezet, mint a földi élet feltétele, és ezáltal per se érték. $A z$ emberi jogok védelmének előfeltétele a környezet védelme, amiből következik, hogy az egyéni szabadságjogok korlátozhatóak a természet védelme érdekében, amely az emberi fajt is magában foglalja. Az egészséges környezethez való jog alanya $\mathrm{e}$ megközelítésben inkább a kollektíva, mint az egyén. Az alanyoknak joguk van meghatározni, hogy a saját környezetük és a természeti erőforrásaik milyen védelemben részesüljenek. $E$ megközelítés a védelmi kört már a lehető legjobban kiterjesztené: önálló jogként kezeli az egészséges környezethez való jogot, amely alanyi jogként is megjelenik a már jól ismert eljárási jogok mellett. Az alanyok tekintetében viszont inkább a kollektív jogvédelemre koncentrál. Az egyéni jogvédelem általában mellékesen jelenik meg az ökocentrikus jellegü szemléletekben. $E$ nézőpont a környezetet nem az ember javát szolgáló „áruként” kezeli, hanem mint az emberi közösséget 
körülvevő, önmagából fakadó értéket. Az ökocentrikus szemlélet szerint nem azért kell védeni a környezetet, mert az az emberi élet fenntartásának záloga, hanem mert a környezet per se értéket jelent. Felmerül azonban a kérdés, hogy ez a nézet valóban emberi jogvédelemröl szól-e? Nem lépett-e már túl azon? Beszélhetünk-e egy olyan emberi jogról, amelynek a védendő értéke végső soron nem az ember és az emberi méltóság? Nem veszélyezteti-e továbbá a már el/felismert emberi jogok implementálásának hatékonyságát egy újabb emberi jog elismerése ${ }^{6}$

A két fő megközelítés lényeges elemeit az alábbi táblázat szemlélteti, az alapján, hogy az adott megközelítés:

- önálló emberi jogként képzeli-e el az egészséges környezethez való jogot (1. sor),

- mely generációs jogi csoporthoz kapcsolja azt (2. sor),

- mit tekint a jog tárgyának (3. sor),

- hogyan határozza meg az alanyi kört (4. sor), valamint

- milyen széles védelmet rendel az egészséges környezethez való joghoz (5. sor).

1. táblázat. Az antropocentrikus és az ökocentrikus megközelítések összehasonlítása

\begin{tabular}{|l|l|l|}
\hline \multicolumn{1}{|c|}{} & \multicolumn{1}{|c|}{$\begin{array}{c}\text { Antropocentrikus } \\
\text { megközelítés }\end{array}$} & \multicolumn{1}{c|}{$\begin{array}{c}\text { Ökocentrikus } \\
\text { megközelítés }\end{array}$} \\
\hline Önálló emberi jog & Nem & Igen \\
\hline Generáció & $\begin{array}{l}\text { Első generációs, polgári és } \\
\text { politikai jogok }\end{array}$ & $\begin{array}{l}\text { Harmadik generációs, } \\
\text { szolidaritási jogok }\end{array}$ \\
\hline Védendő érték & $\begin{array}{l}\text { Emberi élet, magánélet } \\
\text { és a tulajdon védelme a } \\
\text { környezeti károkozástól }\end{array}$ & $\begin{array}{l}\text { Környezet mint per se } \\
\text { érték védelme }\end{array}$ \\
\hline Alany & Egyén & Kollektíva \\
\hline Védelem szintje & Eljárási jogok & Alanyi és eljárási jogok \\
\hline
\end{tabular}

\section{Emberi jogi attribútumok}

Az emberi jogok a nemzetközi jog által védelem alá vont olyan, az emberi méltóságból fakadó normák, amelyek az állami szuverenitás morális korlátait jelentik. ${ }^{7} \mathrm{Az}$

${ }^{6} \mathrm{Az}$ antropocentrikus, illetve az ökocentrikus megközelítésröl bővebben lásd Birnie-Boyle-Redgwell: i. m., 272; Boyle (2011) i. m., 471-472; Mushkat: i. m., 163; Bándi (2012) i. m., 10; Nickel-MagraW: i. m., 453-471; Hiskes, i. m., 1346-1364; Shelton, Dinah: Human Rights, Environmental Rights, and the Rights to Environment. Standford Journal of International Law, 1991-92, 103-138; Fitzmaurice: i. m., 590-608; Gosseries, Axel: On Future Generations' Future Rights. Journal of Political Philosophy, 2008, 446-474; WEISs, Edith Brown: Our Rights and Obligations to Future Generations for the Enironment. Americal Journal of International Law, 1990, 198-207; Human Rights and the Environment, Rio+20: Joint Report OHCHR and UNEP, Brazil, 2012; TURNER, Stephen J.: A Substantive Environmental Right. Wolters Kluwer Law \& Business, 2008, 46-79; BOYLE (2015) i. m.

7 RAZ, Joseph: Human Rights without Foundations, 337, In: Besson, Samantha-Tasioulas, John (eds.): The Philosophy of International Law. Oxford University Press, 2010. 
általánosan elfogadott nézet szerint ${ }^{8}$ az egyének és szük körben csoportok nemzetközi szerződésekben, valamint nyilatkozatokban ilyenként elismert jogait és szabadságait nevezzük emberi jogoknak, amelyek az egyén emberi mivoltából fakadnak, és az emberi méltóság feltétlen tiszteletén alapulnak, és melyekkel minden egyén rendelkezik, függetlenül az egyén tulajdonságaitól vagy szociális környezetétől. ${ }^{9}$

A nemzetközi emberi jogok gyakran állnak kritikák kereszttüzében, különösen a fenti fogalomból is következő univerzális, illetve abszolút jelleget illetően, ami nem áll feltétlenül összhangban napjaink pozitivista jogszemléletével. A nemzetközi jog az emberi jogokat ugyanis általánosan az emberi méltóságból eredezteti, azzal igazolja. 1948. december 10-én „nagy formátumú politikusok és szerényebb képességü társaik, kiemelkedő jogászok és a diplomácia kipróbált rókái az egymást gyötrö vitákban olyan dokumentumot formáltak, amelyet az egyének, az államok és az emberiség alapvető viszonyítási pontnak tudnak tekinteni ma is". ${ }^{10} \mathrm{Ez}$ a dokumentum az ENSZ Közgyülése által 1948. december 10-én elfogadott Emberi Jogok Egyetemes Nyilatkozata (a továbbiakban: Egyetemes Nyilatkozat vagy EJENY), amely az 1. cikkében kimondja, hogy minden ember szabadon születik, és egyenlő méltósága és joga van. Az emberi méltóság egy végtelenül összetett és elvont fogalom, amely az emberi jogokat szükségszerüen a természetjoghoz kapcsolja, és amit - csakúgy, mint a jog, a szabadság, az igazságosság, vagy éppen az autonómia fogalmait - nagyon nehéz, ha lehetséges egyáltalán definiálni. Általánosan elfogadott, hogy az ember létezéséből fakadóan rendelkezik méltósággal, amely értéket mindenki másnak tiszteletben kell tartania. Méltóságának tiszteletben tartása minden embert megillet, és így a méltóság minden embert össze is köt valamilyen szinten.

Az általános nézőponttól eltérően Samantha Besson nem a méltóságot, hanem az egyenlőséget (equality), pontosabban az egyenlő moráli státuszt (equal moral status) tartja az emberi jogok alapjának, és ezáltal igazolásának. Besson szerint minden személyt (person) úgy kell kezelni, hogy azok egyforma morális értékkel bírnak, valamint ez az érték összefügg és egyben az alapja a kölcsönös morális igényeknek. Ez alapján egyetlen személy sem lehet morálisan más személynek alárendelve. A méltósággal Besson szerint pont azt fejezzük ki, ami minden emberi lényben közös: a racionalitásra és a moralitásra való képességünket. ${ }^{11}$ Akik tehát rendelkeznek racionalitásra és moralitásra való képességgel, azok ugyanolyan morális státusszal rendelkeznek. Az egyén önmagában érték, és ez alapján egyenlő

8 Human rights, In: Max Planck Encyclopedia of Public International Law; Buergenthal, Thomas, 1.; HenderSON, C. W.: Understanding International Law. Wiley-Blackwell, 2010, 288; KLABBeRS, Jan: International Law. Cambridge University Press, 111; SHAw, Malcolm N.: International Law. Cambridge University Press, 2014, 194-195; SHeLton, Dinah: Advanced Introduction to International Human Rights Law. Edward Elgar Publishing, Cheltenham, 2014, 1-4; Clayton, Richard-Tomlinson, Hugh (eds.): The Law of Human Rights. Second Edition, Volume 1, Oxford University Press, 2009, 1.15, 25.

9 A fenti definíció nem teljes körủen, de általánosan elfogadott. Egyes gondolkodók egyenesen tagadják az emberi jogok létét. MacIntyre a nyolcvanas évek elején az emberi jogokat például a boszorkányokban és az egyszarvúkban való hithez hasonlította. MAclNTYRE, Alasdair: After Virtue. Duckworth, 1981.

10 KovÁcs Péter: Az Emberi Jogok Egyetemes Nyilatkozata kidolgozásának története és elfogadásának körülményei. Iustum Aequum Salutare, 2009/2, 66.

11 Besson, Samantha: Justifications. In: Moeckli, Daniel-Shah, Sangeeta-Sivakumaran, Sandesh (eds.): International Human Rights Law. Oxford University Press, 2. kiadás, 2014, 46. 
másokkal, így a státusza és morális értéke másokkal való kapcsolatában határozható meg. Az egyenlő morális státusz nem egyszerüen egyenlő igényekkel/követelésekkel (claim) ruházza fel az egyéneket. A kölcsönös igényekre hivatkozás definiálja az egyenlő morális státuszt. A kölcsönös jogosultságokat, amelyek az egyenlő morális státuszban benne rejlenek, Besson kölcsönös alapvető morális jogoknak nevezi. Ez alapján az emberi jogok azon alapvető morális jogok, amelyek egyenlő morális státuszt biztosítanak. Azaz nem minden alapvető morális jog emberi jog, csak azok, amelyek egyenlő morális státuszt biztosítanak. Az alapvető morális jogok a tág értelemben vett egyenlő bánásmódot és tiszteletet jelentik. Az emberi jogok azonban csak azon alapvető morális jogokat védik, amelyek kölcsönös jogosultságokat keletkeztetnek. ${ }^{12}$

Az emberi jogok által biztosított egyenlö morális státusz tehát azt jelenti, hogy az egyéneket a jog és a jogi intézmények egyenlőként kezelik. Az emberi jogok így a jog előtti egyenlőséget, politikai egyenlőséget biztosítják, és ezáltal érik el az emberi méltóság védelmét is. $E$ gondolatmenettel összhangban áll az Egyetemes Nyilatkozat 2. cikke, miszerint a ,jelen nyilatkozatban megfogalmazott összes jogok és szabadságok fajra, színre, nemre, nyelvre, vallásra, politikai vagy más véleményre, nemzeti vagy társadalmi származásra, vagyonra, születésre vagy más körülményre vonatkozó mindennemü megkülönböztetés nélkül mindenkit megilletnek. Ezenkívül semmiféle megkülönböztetést nem lehet tenni annak az országnak vagy területnek a politikai, jogi vagy nemzetközi helyzete alapján, amelynek a személy állampolgára, tekintet nélkül arra, hogy az adott ország vagy terület független, gyámság alatt áll, nem rendelkezik önkormányzattal vagy szuverenitása bármely vonatkozásban korlátozott." ${ }^{13}$ Ennek a cikknek jelen elméleti fejtegetés szempontjából több tekintetben is kiemelkedő jelentősége van. Egyrészről igazolásként is szolgálhat az egyenlőség fentebb vázolt szerepére az emberi jogok terén. Másrészről, mint az egyetlen univerzális nemzetközi szervezet intézménye által létrehozott dokumentum - amely kétséget kizáróan a nemzetközi emberi jogi védelem referenciadokumentumának tekinthető -, alátámasztja az emberi jogok egyetemes jellegét. Az emberi jogok tehát - minden kritika ellenére - egy olyan egyetemesen elfogadott eszmerendszert képviselnek, amely napjainkban a jelen állás szerint morális korlátokat jelent az ENSZ 193 állama számára. Az emberi jogok létjogosultsága ennek értelmében nem határolható le egy-egy földrajzi régióra.

Besson szerint az emberi jogok nem egyszerủen az egyének (individuals) egyenlő politikai státuszának a következménye, hanem egyúttal ezen egyenlő státusz megteremtése és megszilárdítása is. Emberi jogok nélkül a politikai egyenlőség csak egy elvont kategória, mivel az emberi jogok által válnak az egyének a politikai közösségük tagjaivá, alanyaivá. Besson szavaival vág össze Hannah Arendt véleménye is, aki szerint nem születünk egyenlönek, hanem egy kollektíva egyenlö tagjaivá válunk azon döntésünk alapján, hogy saját magunk számára kölcsönösen egyenlő jogokat biztosítsunk. ${ }^{14}$ Véleményem szerint éppen a méltóság (racionalitásra és moralitásra

\footnotetext{
Besson: i. m., 44-45.

13 Emberi Jogok Egyetemes Nyilatkozata 2. cikk.

14 Besson: i. m., 46.
} 
való képesség) okán születünk egyenlőnek. Az egyenlöség (egyenlő morális státusz) tehát adott: azt megteremteni nem, de védeni kell. A védelem pedig az emberi jogok által érhető el, azaz Besson alapján azon alapvető morális jogok által, amelyek egyenlő morális státuszt biztosítanak.

A fentieket összegezve emberi jogoknak nevezzük azon alapvető morális jogokat, amelyek kölcsönös jogokat és kötelezettségeket keletkeztetve egyenlő morális státuszt biztosítanak alanyai számára, ezáltal védve az emberi méltóságot. Az emberi méltóság védelme tehát az emberi jogok absztrakt/általános célja. Az absztrakt cél eléréséhez vezető megvalósítási mód pedig a jog előtti egyenlőség biztosítása. A méltóság arra vonatkozóan ad támaszpontot, hogy milyen vonatkozásokban szükséges az egyenlőség biztosítása. Az emberi jogok ezen ismérveit az alábbi táblázat szemlélteti.

2. táblázat. Az emberi jogok ismérvei

\begin{tabular}{|l|l|}
\hline & \multicolumn{1}{|c|}{ Emberi jogok } \\
\hline Jogelméleti háttér & Természetjog \\
\hline Tárgyi jog forrásai & Nemzetközi szerződések, soft law dokumentumok \\
\hline Megvalósítási mód & Egyenlö morális státusz biztosítása \\
\hline Általános cél & Méltóság védelme \\
\hline Általános tárgy & Méltóság \\
\hline Speciális cél & Adott emberi jog tárgyának védelme, pl.: tulajdon védelme \\
\hline Speciális tárgy & Adott emberi jog védendő értéke, pl.: tulajdon \\
\hline Jogalany & Egyén és kollektíva \\
\hline Jelleg & Egyetemesség és oszthatatlanság \\
\hline Hatály & Erga omnes \\
\hline
\end{tabular}

Milyen emberi jogokról beszélhetünk napjainkban? Az alábbiakban felvázolom, hogy mely emberi jogokat helyezte már a nemzetközi jog védelem alá. E cél elérése érdekében három emberi jogi katalógust vizsgálok: a már említett Egyetemes Nyilatkozatot; a Polgári és Politikai Jogok Nemzetközi Egységokmányát (a továbbiakban: PPJNE); valamint a Gazdasági, Szociális és Kulturális Jogok Nemzetközi Egységokmányát (a továbbiakban: GSZKJNE).

Az EJENY, bár kötelező jelleggel nem bír, hagyományos alapját képezi az emberi jogok nemzetközi védelmének, és „az alapvető emberi jogok egyik referenciadokumentumának tekinthető"15 csakúgy, mint a PPJNE vagy a GSZKJNE. Az említett nemzetközi jogi dokumentumok továbbá, ahogyan azt az összefoglaló nevük is jelzi, - International Bill of Human Rights - központi helyet foglalnak el a nemzetközi emberi jogban, így véleményem szerint megfelelőek arra, hogy tartalmukból általános következtetéseket lehessen levonni arra vonatkozóan, hogy mely emberi jogokat helyezi a nemzetközi jog napjainkban védelem alá.

15 Kardosné Kaponyı Erzsébet: Az emberi jogok nemzetközi védelme. PhD-értekezés, Budapest, $2000,91$. 
Az EJENY föleg polgári és politikai jogokat tartalmaz, úgymint: ${ }^{16}$

- egyenlőség (1. cikk),

- a diszkrimináció általános tilalma (2. cikk),

- az élethez, szabadsághoz és biztonsághoz való jog (3. cikk),

- a rabszolgaság és rabszolga-kereskedelem tilalma (4. cikk),

- a kínzás tilalma (5. cikk),

- a törvény elötti jogalanyiság elismerésének joga (6. cikk),

- a törvény elötti egyenlőség és a törvény egyenlő védelme (7. cikk),

- tényleges jogorvoslathoz való jog (8. cikk),

- az önkényes letartóztatás tilalma (9. cikk),

- a tisztességes tárgyaláshoz való jog (10. cikk),

- az ártatlanság vélelme és a nullum crimen sine lege elve (11. cikk),

- a magán- és családi élet tiszteletben tartásához való jog (12. cikk),

- a szabad mozgáshoz való jog (13. cikk),

- menedékjog (14. cikk),

- állampolgársághoz való jog (15. cikk),

- a házassághoz és családalapításhoz való jog (16. cikk),

- a tulajdonhoz való jog (17. cikk),

- gondolat-, lelkiismeret- és vallásszabadság (18. cikk),

- a véleménynyilvánítás szabadsága (19. cikk),

- a gyülekezés és egyesülés szabadsága (20. cikk),

- a közügyekben való részvételhez való jog (21. cikk).

A felsorolt jogokat első generációs jogoknak is szokás nevezni, ${ }^{17}$ amelyek a fejlödéshez, a polgárosodáshoz és az ezzel kapcsolatos önmegvalósításhoz kapcsolódtak, így azok részben politikai szabadságjogok, részben pedig vagyoni, tulajdoni érdekü jogok. A polgári és politikai jogok eszközöket és szabadságokat biztosítanak az egyének számára a társadalmon belül. Ezek a jogok az egyénhez kötöttek, az állam és a társadalom hatalmával és autoritásával szemben.

A nyilatkozatban találunk szociális, gazdasági és kulturális jogokat is (ún. második generációs jogokat), úgymint:

- a szociális biztonsághoz való jog (22. cikk),

- a munkához való jog (23. cikk),

- a pihenéshez való jog (24. cikk),

- az egészség és jóllét biztosításához alkalmas életszínvonalhoz való jog (25. cikk),

- az oktatáshoz való jog (26. cikk), valamint

- a kultúrához és tudományhoz való jog (27. cikk).

${ }_{16}$ Az Emberi Jogok Egyetemes Nyilatkozatának magyar szövegét lásd: http://www.ohchr.org/EN/UDHR/ Documents/UDHR_Translations/hng.pdf (2016. 01. 15.).

17 Karel Vašak csehszlovák származású jogász nevéhez fűződik az emberi jogok generációinak elmélete. A generációk kifejezést 1977-ben használta először, amikor az emberi jogokat a francia forradalom hármas jelszavához kapcsolta. Ebben az értelemben a szabadságot a klasszikus polgári és politikai jogok, az egyenlöséget a gazdasági és szociális és kulturális jogok, a testvériséget pedig a szolidaritási jogok jelentik. Lásd VAŠAK, Karel: Human Rights: A Thirty-Year Struggle: the Sustained Efforts to Give Force of Law to the Universal Declaration of Human Rights. UNESCO Courier, Vol. 30. No. 11, 1977, 316-325. 
A gazdasági, szociális és kulturális jogok az egyének és közösségek életminőségéhez kötődnek. Ezek a jogok célokat képviselnek, amit minden államnak elérhetövé kell tennie az állampolgárai számára.

Beszélhetünk ugyanakkor harmadik generációs emberi jogokról is, amelyek globális kihívásokra reagálnak az élet egyetemes védelme érdekében. ${ }^{18} \mathrm{~A}$ harmadik generációs jogokat szolidaritási jogoknak is nevezik, amelyek alanyi köre inkább a kollektíva, mint az egyén, biztosításukhoz továbbá nemzetközi együttmüködés szükséges. Általánosan elfogadott álláspont alapján a szolidaritási jogok közé sorolhatóak inter alia az egészséges környezethez való jog, a békéhez való jog vagy a fejlődéshez való jog. Az első két generációba tartozó jogok a nemzetközi jogban már széles körben elismertek, amíg az ún. harmadik generációs emberi jogoknak még utat kell törniük maguknak: el/felismerésük a globális problémák jelentkezésével áll összefüggésben. Ez az oka annak, hogy az EJENY nem tartalmaz szolidaritási, vagyis harmadik generációs emberi jogokat.

Nyolc évvel az EJENY kidolgozása után elkészült a PPJNE, valamint a GSZKJNE. Ezen egységokmányok kibontják az Egyetemes Nyilatkozatban felsorolt jogokat, kiterjesztik a védelmet, illetve új jogokat is megfogalmaznak. E forrásokban már külön jogként szerepel:

- a szakszervezethez való jog (GSZKJNE 8. cikk),

- a szociális biztonsághoz való jog (GSZKJNE 9. cikk),

- az ételhez való jog (GSZKJNE 11. cikk),

- a jogképességhez való jog (PPJNE 16. cikk),

- az egészséghez való jog (GSZKJNE 12. cikk) és

- a müvelödéshez való jog (GSZKJNE 13. cikk).

Kiemelt védelmet kap továbbá a gyermek (PPJNE 24. cikk, GSZKJNE 10. cikk), valamint a család mint a társadalom természetes és alapvető egysége (GSZKJNE 10. cikk). Külön tilalmazott a törvényes határozat nélküli kiutasítás (PPJNE 13. cikk), illetve a bebörtönzés kizárólag abból az okból, hogy valaki nem képes szerződéses kötelezettségének eleget tenni (PPJNE 11. cikk). Fontos „újdonság” továbbá, hogy emberi jogként kerülnek elismerésre olyan kollektív jogok, mint a népek önrendelkezési joga (PPJNE 1. cikk, GSZKJNE 1. cikk) vagy a kisebbségi jogok (PPJNE 27. cikk).

A listából látható, hogy a nemzetközi jog által eddig védelem alá vont emberi jogok köre meglehetösen széles és sokszínü. Annak ellenére, hogy a felsorolt emberi jogok tárgyai természetükben szerfelett eltérőek lehetnek (emberi élet, tulajdon, jogképesség, oktatás stb.), azokat az emberi méltóság mégis összeköti.

Az emberi jogok nemzetközi rendszerének nem a béke megteremtése a célja, és még csak nem is az igazságosság elösegítése, hanem a jog előtti egyenlőség biztosítása által az emberi méltóság védelme.$^{19} \mathrm{Az}$ kézenfekvő, hogy az emberi méltóság

18 BÁNDI: i. m., 59.

19 Griffin, James: Human Rights and the Autonomy of International Law. In: Besson, Samantha-Tasioulas, John (eds.): Philosophy of International Law. Oxford University Press, New York, 2010, 339-356. 
sérelme nem minden esetben idézi elő emberi jog sérelmét, valamint nem minden az emberi méltósággal összefüggésbe hozható - élethelyzet fedhető le egy emberi joggal.

Ha vetünk egy pillantást a felsorolt emberi jogokra és azok stricto sensu tárgyaira, akkor láthatjuk, hogy a méltóság absztrakt kategóriája olyan - kevésbé elvont - kifejezésekben ölt testet, mint például az élet, szabadság, biztonság, jogalanyiság, jogorvoslat, tisztességes tárgyalás, állampolgárság, házasság, tulajdon, munka, pihenés, oktatás, egészség, kultúra, tudomány vagy a művelődés. Ezek a fogalmak végső soron mind a méltósághoz kötődnek, és igényeket, vagy más szóval szükségleteket fejeznek ki. ${ }^{20}$ Olyan szükségleteket jelölnek, amelyek közvetve ugyan, de a méltóságot (egyenlő morális státuszt) biztosítják. A szükségletek kielégítése motiválja a tetteinket. Az alapvető szükségletek (táplálkozás, regenerálódás, biztonság, információ iránti szükséglet stb.) az emberhez méltó élet feltételeinek a leképezödései, melyek hozzávetőleg minden ember számára hasonló elemeket jelentenek, mindössze fontosságukat illetően beszélhetünk különbségekröl. A szabadság, a biztonság, a kötődés, a kiteljesedés, a megismerés stb. iránti igényeink kifejeződéseit láthatjuk a felsorolt emberi jogok tárgyaiban. A szükséglet tehát az a tényező, amely egyfajta filterfunkciót ellátva kiemeli azokat az emberi méltósággal kapcsolatos élethelyzeteket, amelyek alkalmasak emberi jogvédelemre.

Milyen kapcsolatban állnak ez alapján a szükségletek, az emberi jogok és a méltóság egymással? Az előzőekben listázott emberi jogok tárgyai közvetve védik az emberi méltóságot. Továbbá minden emberi jog megfeleltethető egy vagy több szükségletnek, csakúgy, ahogyan minden szükséglet kifejezhető egy vagy több emberi joggal. Az ember szükségletei alapján határozza meg magát, ezáltal a vele született méltóságát. Az emberi szükségletek tehát a méltóság bizonyos szintű leképezését jelentik. A méltóság persze nem fedhetö le teljesen a szükségleti kategóriákkal, az ennél összetettebb és érzékenyebb fogalom. A méltóságnak mindig marad egy, a szükségletek által le nem fedhető része, és e jellemvonásnak köszönhetően képes a szükséglet kategóriája kiemelni az emberi méltóság elvont fogalmából azokat az élethelyzeteket, amelyekre a jog érdemben reagálni képes. Ennek köszönhetően az emberi szükségletek egyfajta filter/becsatornázási funkciót látnak el az emberi méltóság és az emberi jogok között. A szükségletek csatornázzák be a méltóság elvont fogalmának a jog által értelmezhető elemeit. Az emberi jogok - méltóság - szükségletek háromszög ugyanakkor kiegészíthető az egyenlőség fogalmával is. Az egyenlő morális státusz (emberi jogok) védelme a jog előtti egyenlőség biztositásával érhető el. Azáltal, hogy minden egyén számára biztosított bizonyos jogok egyenlő védelme (azon jogok védelme, amelyek a méltóság elvont fogalmából a szükségletek által lettek kiemelve és becsatornázva), minden ember egyenlő morális státusza jut érvényre. Következésképpen az emberi jogok, az egyenlőség, a szükségletek és az emberi méltóság viszonya a következőképpen ábrázolható és írható le.

20 A szükségletelméletekről bővebben lásd StaVEnhagen, Rodolfo: Needs, Rights and Social Development. United Nations Research Institute for Social Development, 2003. 


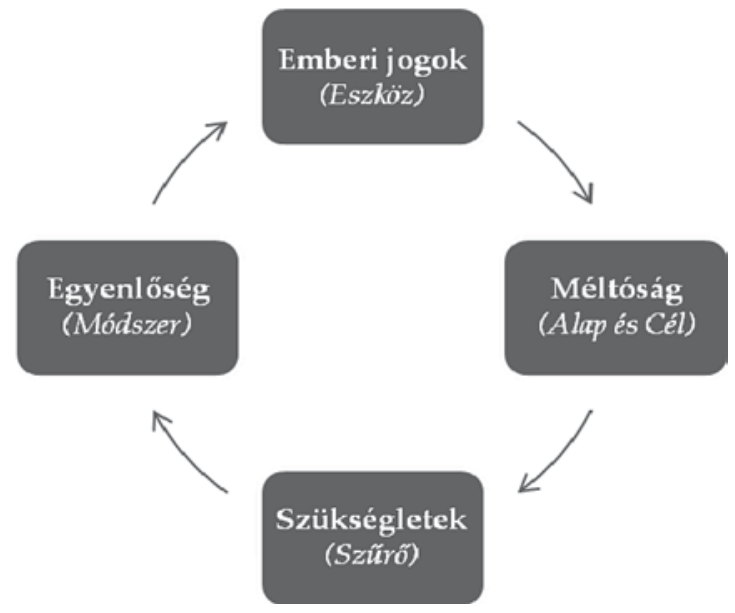

2. ábra. Az emberi jogok, a szükségletek, az egyenlőség és a méltóság viszonya

- A méltóság és a szükségletek kapcsolata: A méltóság absztrakt halmazából a szükségletek emelik ki a jog által értelmezhető élethelyzeteket. A szükségletek az emberhez méltó életfeltételeket fejezik ki.

- A szükségletek és az egyenlőség kapcsolata: A szükségletek által kiemelt élethelyzetek azok, amelyek alkalmasak emberi jogi védelemre. Az emberi jogok speciális tárgyai így hozzárendelhetőek egy-egy szükséglethez.

- Az egyenlóség és az emberi jogok kapcsolata: Az emberi jogok védelme az egyenlőség (egyenlő morális státusz) biztosításával valósítható meg.

- Az emberi jogok és a méltóság kapcsolata: Az emberi jogok az ember vele született méltóságára vezethetőek vissza. Az emberi jogok célja és általános tárgya a méltóság védelme.

\section{Az egészséges környezethez való jog rendszerbe illesztése}

Az egészséges környezethez való jog körül kialakult helyben álás a státusza körüli bizonytalanságból fakad. Az ember és a környezet kapcsolatát vizsgáló nézetek egyik végpontja az antropocentrikus nézőpont, amely a minimalista hozzáállásával nem aknázza ki e jog kínálta lehetőségeket. A másik végpont az ökocentrikus megközelítés, amelynek céljai bár kívánatosak, azok nem illeszkednek az emberi jogok védelmének rendszerébe. A feladat tehát egy olyan jognak az emberi jogi rendszerbe illesztése, amelynek védendő értéke a környezet, de végső soron mégiscsak az emberi érdekeket tartja szem előtt. Ebben segít a szükségletek kategóriája.

Ahogyan az megállapításra került, emberi jogoknak nevezzük azon alapvető morális jogokat, amelyek kölcsönös jogokat és kötelezettségeket keletkeztetve egyenlő morális státuszt biztosítanak alanyaik számára, így védve az emberi méltóságot. A szükségletek azok a tényezők, amelyek egyfajta filterfunkciót ellátva kiemelik azo- 
kat az emberi méltósággal kapcsolatos élethelyzeteket, amelyek alkalmasak emberi jogvédelemre.

A kérdés a szükségleti teszt alapján az, hogy kötődik-e valamely szükséglethez a környezethez való jog, biztosítva ezzel az emberi méltóságot? Magától értetődő, hogy egy olyan környezet, amelynek elemei - a flóra, fauna, talaj, víz, levegö és az ezek közötti kölcsönhatások - nem járulnak hozzá a fizikai és szellemi egészség megőrzéséhez, vagy egyenesen károsak azokra, az csorbítja az emberi méltóságot. Egy olyan környezet iránti igény, amely nem veszélyezteti az emberi egészséget, és ezáltal biztosított az egészségre nem káros étel, víz, valamint életkörnyezet, az egyértelműen alapvető szükségleteket fejez ki. A környezet védelme által védi az ember saját magát is, hiszen az ember a környezet része. Az ember függ környezetétöl: csak megfelelö (egészséges) környezet esetén képes az ember megfelelő életközeghez, vízhez, ételhez és levegöhöz jutni. Az egészséges környezet biztosítása így teszi lehetővé az emberi élet fenntartását, és így kapcsolódik egyszerre a fiziológiai szükségletekhez és a méltóság morális normájához. Nem beszélhetünk emberhez méltó életfeltételekröl, ha a környezet elemei olyan mértékben szennyezettek, hogy az károsítja az egészséget. Mivel az ember, mint a környezet része, ezt a rendszert belülröl rombolja, a nevezett szükséglettel kapcsolatos fö igény az ember általi azon környezeti károkozások meggátolása, melyek veszélyeztetik az emberi egészséget, rövid vagy akár hosszú távon.

Az egészséges környezethez való jog tehát az élet minőségét és fennmaradását szolgálja ${ }^{21}$ azáltal, hogy biztosítja az emberi élethez megfelelő közeget (ezáltal hozzájárulva az egészséges ételhez), pl. levegőt és vizet. Az egészséges környezethez való jog azokat az igényeket garantálja, amelyek az emberi élet fenntartásához szükségesek. Következésképpen az egészséges környezethez való jog speciális tárgya (környezet) az alapvető szükségleteknek mindenképpen megfeleltethetö, és mint ilyen, általános célja a méltóság védelme, míg speciális célja a környezet védelme.

Az alábbi ábra az emberi jogok és az egészséges környezethez való jog viszonyát szemlélteti. Az emberi jogok rendszere a jog válasza az emberi méltóság védelmére, így a legkiterjedtebb halmaz a méltóságé, amelyben megtalálhatóak az emberi jogok, hiszen azok az ember elidegeníthetetlen méltóságából fakadnak. Az egészséges környezethez való jog rendelkezik azokkal a kívánalmakkal, amelyek egy jogot alkalmassá tesznek nemzetközi emberi jogi védelemre, így az egészséges környezethez való jog az emberi jogok halmazán belül helyezkedik el. A legkisebb kört az egészséges környezethez való jog tárgya képezi: egy olyan környezet, amely nem károsítja vagy veszélyezteti az ember egészségét.

21 BÁNDı Gyula: A környezethez való jog aktualitása. Rendészeti Szemle, 2009/1, 20. 


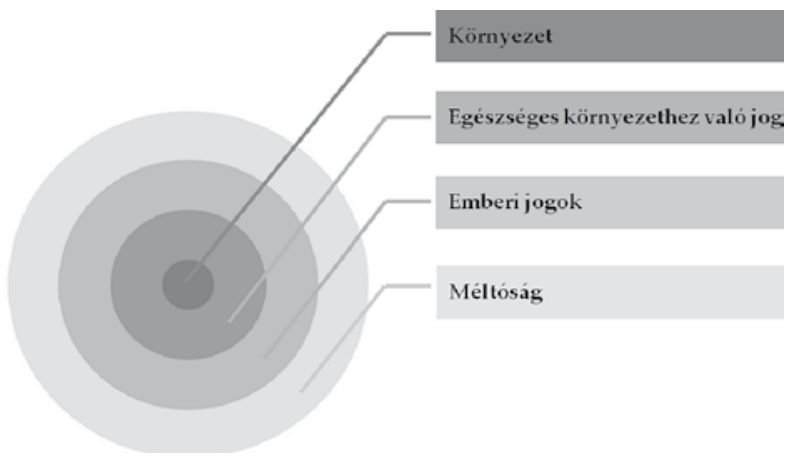

3. ábra. A méltóság, az emberi jogok, az egészséges környezethez való jog és a környezet viszonya

Az egészséges környezethez való jog tehát egy emberi jog, amely a környezetet nem önmagából fakadó értéke miatt védi, hanem annyiban, amennyiben az az emberi méltóság biztosításához szükséges. A környezet per se védelme, bár az mindenképpen üdvözlendő és szükséges cél, az emberi jogi védelem keretei között nem megvalósítható, ugyanis az emberi jogok védelmének per se értéke csak az emberi méltóság lehet. A környezet per se védelmére tehát más megoldást kell találni, az emberi jogvédelem rendszerén kívül. Az egészséges környezethez való jog szük értelemben vett célja tehát a környezetnek mint az emberi létfenntartás feltételének a védelme, speciális tárgya pedig így a környezet.

\section{4. Összegzés}

Az emberi jogok és a környezet védelme közötti kapcsolat kiindulópontja az a tény, hogy meghatározott környezeti károkozás sérthet egyes emberi jogokat, valamint az egészséges környezet elősegíti bizonyos emberi jogok élvezetét. E komplex összefüggésrendszerrel kapcsolatos nézetek alapvetően két véglet körül és között helyezkednek el.

Az egészséges környezethez való jog klasszikus felfogása szerint (antropocentrikus megközelítés) bizonyos, már elismert és védett első generációs polgári és politikai jogokon keresztül (az élethez való jog, a magánélethez való jog, valamint a tulajdonhoz való jog) védhetőek a környezeti eljárási jogok is. Ez a nézet nem tekinti önálló emberi jognak az egészséges környezethez való jogot. Az antropocentrikus felfogás ellenpólusa az ökocentrikus megközelítés, amely az egészséges környezethez való jogot szolidaritási jogként képzeli el, amelynek alanya inkább a kollektíva, mint az egyén. E megközelítés a védelmi kört már a lehető legjobban kiterjeszti: önálló jogként kezeli az egészséges környezethez való jogot, amely alanyi jogként is megjelenik a már jól ismert eljárási jogok mellett. $E$ nézőpont a környezetet nem az ember javát szolgáló „áruként” kezeli, hanem az emberi közösséget körülvevő, önmagából fakadó értékként. 
Az emberi jogok olyan alapvető morális jogok, amelyek kölcsönös jogokat és kötelezettségeket keletkeztetve egyenlő morális státuszt biztosítanak alanyaik számára, ezáltal védve az emberi méltóságot. Az emberi méltóság védelme így az emberi jogok absztrakt/általános célja, amelynek eléréséhez a jog előtti egyenlőség biztosítása vezet. A méltóság arra vonatkozóan ad támaszpontot, hogy milyen vonatkozásokban szükséges az egyenlőség biztosítása.

A nemzetközi jog által eddig védelem alá vont emberi jogok tárgyai természetükben eltérőek, e jogokat az emberi méltóság mégis összeköti. Az emberi méltóság sérelme nem minden esetben idéz elő emberi jogi sérelmet, valamint nem minden az emberi méltósággal összefüggésbe hozható - élethelyzet fedhető le egy emberi joggal. A nemzetközi jog által már elismert emberi jogok stricto sensu tárgyai (inter alia élet, szabadság, biztonság, jogalanyiság, jogorvoslat, tisztességes tárgyalás, állampolgárság, házasság, tulajdon, munka, pihenés, oktatás, egészség, kultúra, tudomány, müvelödés) végső soron egy-egy szükségletet jelölnek, amelyek közvetve biztosítják a méltóságot (egyenlő morális státuszt). A szükségletek azok a tényezők, amelyek egyfajta filterfunkciót ellátva kiemelik a méltóság kategóriájából azokat az emberi méltósággal kapcsolatos élethelyzeteket, amelyek alkalmasak emberi jogi védelemre.

A szükségletek az alapvető biológiai szükségletektől a komplex pszichológiai motivációkig terjedhetnek, melyek között fontossági sorrendet felállítani csak általánosítással lehet, mivel a szükségletek kultúránként, földrajzilag, korszakonként, korosztályonként és nem utolsósorban egyénenként folyamatosan változnak, még ha nem is drámai mértékben. Minden emberi jog megfeleltethető egy vagy több szükségletnek, csakúgy, ahogyan minden szükséglet kifejezhető egy vagy több emberi joggal. Az emberi szükségletek tehát a méltóság bizonyos szintű leképezését jelentik. A méltóság absztrakt halmazából a szükségletek emelik ki a jog által értelmezhető élethelyzeteket. Az emberi jogok speciális tárgyai így hozzárendelhetőek egy-egy szükséglethez.

Egy olyan környezet iránti igény, amelyben biztosított az egészségre nem káros étel, víz, valamint életkörnyezet, az egyértelmüen alapvető szükségleteket fejez ki. $E$ jog mögött meghúzódó legerősebb szükséglet ugyanis annak az igénye, hogy a környezet elemei ne legyenek károsak az ember egészségére. Az egészséges környezethez való jog általános célja a méltóság védelme, míg speciális célja a környezet védelme. Az egészséges környezethez való jog a környezetet emberi jogi eszközökkel védi, így az szükségképpen korlátozott. A környezet az egészséges környezethez való jog alapján nem önmagából fakadó értéke miatt részesül védelemben, hanem azért, mert az az emberi élet alapját képezi, és így az emberi méltóság biztosításához elengedhetetlen. Az egészséges környezethez való jog stricto sensu tárgya tehát a környezet mint az emberi létfenntartás feltétele/az emberi élet természeti alapja, és célja ezek védelme. Ez a tárgy megfeleltethető az alapvető szükségleteknek, amely alkalmassá teszi arra, hogy a nemzetközi jog, az egészséges környezethez való jogot önálló emberi jogként védelem alá vonja.

A környezetvédelem tehát két okból emberi jogi kérdés is. Egyrészt az egészséges környezethez való jog önálló emberi jogként hozzájárul a környezet védelméhez, a környezetszennyezés megelőzéséhez és a természeti erőforrások racionális 
használatához. Másrészt a környezetszennyezés sérthet olyan, az egészséges környezethez való jogon kívüli emberi jogokat is, mint az élethez való jog, a magán- és családi élethez való jog vagy a tulajdon védelméhez való jog. Ezáltal a felsorolt emberi jogok megfelelő védelme is hozzájárul a környezet védelméhez. A környezet emberi jogi eszközökkel való védelme így elméletileg megalapozottnak látszik.

\begin{abstract}
To protect the environment with the help of human rights is one possible way among others to fight against environmental degradation. Yet, does this idea fit into the system of human rights, taking into consideration the fact that the upmost goal of human rights is the protection of human dignity? Is the connection between the environment and the human dignity strong enough to protect the environment by human rights? The following conceptual paper searches for reasonable answers to these questions by analyzing the so-called right to a healthy environment. By doing so the links between human and environmental rights and the specialties of human rights will be examined in order to show why the right to a healthy environment could in theory fit into the system of human rights protection.
\end{abstract}

